\title{
UTILIZATION OF FERMENTED SORREL (Hibiscus sabdariffa L.) SEED MEAL BY WEANER RABBITS
}

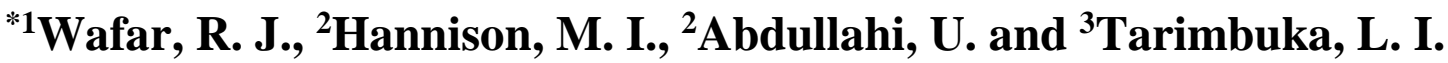

\author{
*l Department of Animal Production and Health, Federal University, Wukari, Taraba State, Nigeria. \\ Phone:08066320686: Email: rjwafari@gmail.com \\ ${ }^{2}$ Department of Animal Science and Range Management, Modibbo Adama University of Technology, Yola, Adamawa State, Nigeria. \\ Phone: 08135999002. Email: talk2moseshannison@gmail.com \\ ${ }^{2}$ Department of Animal Science and Range Management, Modibbo Adama University of Technology, Yola, Adamawa State, Nigeria. \\ Phone: 08032357471 Email: abdullahi324@gmail.com \\ 3Department of Animal Health and Production Technology, Adamawa State College of Agriculture, Ganye, Adamawa State, Nigeria. \\ Phone:07031320840. Email: litarimbuka@gmail.com
}

\begin{abstract}
A 56-day study was conducted to determine the biochemical composition of fermented sorrel seed meal (FSSM) and its effect on the growth performance, carcass characteristics and internal organ weights of weaner rabbits. Forty (40) weaner rabbits with an average weight of 556.89 $\pm 0.10 \mathrm{~g}$ were randomly assigned to five treatment groups of 8 rabbits per treatment replicated four times with 2 rabbits per replicate in a completely randomized design (CRD) for eight weeks. Five experimental diets were compounded using FSSM at 0 , 10, 20, 30 and 40\% inclusion levels. The levels of inclusion were designated as Diets 1, 2, 3, 4 and 5 respectively. The results of the growth performance were not significant $(\mathrm{P}>0.05)$. The result also showed no significant differences $(\mathrm{P}>0.05)$ in carcass characteristics and internal organ weights. It was therefore concluded that fermented sorrel seed meal can be included in weaner rabbit diets up to $40 \%$ level.
\end{abstract}

Keywords: carcass, fermented sorrel seed meal, growth, internal organs, weaner rabbits

LICENSE: This work by Open Journals Nigeria is licensed and published under the Creative Commons Attribution License 4.0 International License, which permits unrestricted use, distribution, and reproduction in any medium, provided this article is duly cited.

COPYRIGHT: The Author(s) completely retain the copyright of this published article.

OPEN ACCESS: The Author(s) approves that this article remains permanently online in the open access (OA) mode.

QA: This Article is published in line with "COPE (Committee on Publication Ethics) and PIE (Publication Integrity \& Ethics)". 


\section{INTRODUCTION}

Soybean meal (SBM) has been recognized as a conventional protein source in the formulation of poultry and rabbit ration Tang et al. (2012). However, high cost of SBM recently has necessitated animal nutritionists to search for alternative sources that are cheaper and readily available. Sorrel seed (Hibiscus sabdariffa L.) is consider as one of such plant. The plant is well adapted to both Guinea and Sudan savanna vegetation of Nigeria (Alagbejo, 2000). The raw seed on dry matter basis contains $35.90 \%$ crude protein, $10.14 \%$ ether extract, $10.09 \%$ ash and 15 - $17 \%$ crude fiber (Dashak and Nwanegbo 2002; Kwari et al., 2011) and also appreciable amount of minerals such as phosphorus, calcium and magnesium (Ismail et al., 2008). The seed has also been reported to possess anti-oxidative and antihypercholesterolemic properties (Ismail et al., 2008; Mahadevan et al. 2009). However, the seed have been reported to contain anti-nutritional factors such as total phenols, tannins and phytic acid, saponins and alkoloids which have limited its utilization by monogastric animals (Diarra et al.,2011 and Wafar, 2013). Hence, proper processing of the seed to aid its utilization by non - ruminant animals is necessary.

Several processing methods have been employed towards reducing the anti-nutritional factors in sorrel seeds to make it useful especially to monogastric animals (Diarra et al. 2011, Kwari et al., 2011; Wafar 2013 and Ashom et al., 2014). These authors concluded from their studies that sorrel seed can be improved through processing. One of the processing methods focused in this study is fermentation. According to Yakubu et al. (2017) fermentation is the breaking down of complex organic substances into simpler ones through the action of enzymes. Through fermentation, B- vitamin is synthesized, mineral extraction abilities increased, as well as reduction in anti-nutrient and fiber contents of feed materials (Oboh, 2006; Aro et al., 2008; Badau et al. (2015). A study by Yakubu et al., (2017) showed that natural fermentation of Jatropha seed improved its utilization in broiler chicken. Recently, Tuluen et al. (2011), reported that natural fermented mucuna seed replaced soyabeans meal in broilers chickens' diet up to $20 \%$ without any deleterious effects on their performance. These reports suggest that natural fermentation could be a promising method in detoxifying anti- nutritional factors in the leguminous seed. This study was therefore conducted to evaluate the growth performance, carcass yield and internal organs characteristics of weaner rabbits fermented sorrel seed meal.

\section{MATERIALS AND METHODS}

Sorrel seeds were procured from Yola market, Adamawa State, Nigeria. 50kg kapok seed was cleaned of debris and cooked for one hour using metallic pot. The pot was placed on a tripod stand having firewood as a source of heat. The timing of the cooking started at the point of boiling after the seeds were introduced. The water was drained immediately after cooking and the seeds packed in a polythene bag to allow natural fermentation to take place. The fermentation process lasted for 120 hours (5days). The fermented sorrel seeds were sundried and milled using hammer milling machine to produce fermented sorrel seed meal (FSSM).

\section{EXPERIMENTAL DIETS, DESIGN AND MANAGEMENT}

Five experimental diets containing 0, 10, 20,30, and 40\% FSSM were formulated (Table 1). Forty (40) weaner rabbits with an average weight of $556.89 \pm 0.10 \mathrm{~g}$ were randomly assigned to the five treatment groups of 8 rabbits per treatment replicated four times with 2 rabbits per replicate in a completely randomized design. The rabbits were housed 
in cage measuring $150 \mathrm{~cm} \times 100 \mathrm{~cm} \times 120 \mathrm{~cm}$ in a three-tier hutch system raised $90 \mathrm{~cm}$ above the floor. The cages were fitted with aluminum feeders and drinkers. The animals were treated against internal and external parasites using Endovef® (Ivermectin) at the dose of $0.3 \mathrm{mg} / \mathrm{kg}$ subcutaneously and also treated prophylactally against coccidiosis with Amprole $200 \circledR$ according to the manufacturer's prescription.

\section{DATA COLLECTION}

\section{GROWTH PERFORMANCE MEASUREMENTS}

Feed intake was determined as the difference between the quantity of feed offered and feed leftover. Similarly, total body weight gain was determined as the difference between the final body weight and initial body weight recorded at the beginning of experiment. Feed conversion ratio was calculated the ratio of feed intake to weight gain.

\section{CARCASS AND INTERNAL ORGANS EVALUATION}

One rabbit from each replicate was randomly selected for carcass and internal organs evaluation according to the method described by Yakubu and Wafar (2014). The rabbits were weighed individually, slaughtered and de-pelted completely to obtain pelt weight. The internal organs were removed carefully and weighed using electronic sensitive scale and expressed as percentages of their live bodyweight. The dressing percentage was calculated as a ratio of carcass weight and live weight multiplied by 100 .

Table 1: Ingredient Composition of experimental diets (8 weeks)

\begin{tabular}{llllll}
\hline & \multicolumn{5}{c}{ Dietary treatments } \\
\cline { 2 - 5 } Ingredient & $\mathrm{T} 1(0 \%)$ & $\mathrm{T} 2(10 \%)$ & $\mathrm{T} 3(20 \%)$ & $\mathrm{T} 4(30 \%)$ & $\mathrm{T} 5(40 \%)$ \\
\hline Maize & 53.50 & 53.50 & 53.50 & 53.50 & 53.50 \\
FSSM & 0.00 & 2.50 & 5.00 & 7.50 & 10.00 \\
Soyabean (fullfat) & 25.00 & 22.50 & 20.00 & 17.50 & 15.00 \\
Fishmeal & 3.00 & 3.00 & 3.00 & 3.00 & 3.00 \\
Maize Offal & 15.00 & 15.00 & 15.00 & 15.00 & 15.00 \\
Bone meal & 2.50 & 2.50 & 2.50 & 2.50 & 2.50 \\
Methionine & 0.25 & 0.25 & 0.25 & 0.25 & 0.25 \\
Lysine & 0.25 & 0.25 & 0.25 & 0.25 & 0.25 \\
Salt & 0.25 & 0.25 & 0.25 & 0.25 & 0.25 \\
Premix & 0.25 & 0.25 & 0.25 & 0.25 & 0.25 \\
Total & 100.00 & 100.00 & 100.00 & 100.00 & 100.00 \\
Determined analysis & & & & & \\
Dry matter & 90.67 & 90.12 & 90.34 & 90.04 & 90.12 \\
Crude protein & 17.79 & 17.78 & 17.76 & 17.75 & 17.74 \\
Crude fibre & 4.28 & 4.37 & 4.46 & 4.55 & 4.65 \\
Ether extracts & 7.20 & 6.88 & 6.59 & 6.24 & 5.92 \\
Ash & 4.29 & 4.37 & 4.46 & 4.55 & 4.65 \\
NFE & 66.44 & 66.60 & 66.73 & 66.91 & 67.04 \\
ME (Kcal/kg) & 3118.00 & 3117.02 & 3116.03 & 3115.05 & 3114.07 \\
\hline
\end{tabular}


Vitamin-mineral premix provider per kg the following: Vit. A 1500 IU; Vit.D 3000 IU; Vit.E 30 IU; Vit. K 2.5 mg; Thiamine 3 mg; Riboflavin 6 mg; Pyrodoxine 4 mg; Niacin 40 mg; Vit. B12 0.02 mg; Pantothenic acid 10 mg; Folic acid 1 mg; Biotin 0.08 mg; Chloride 0.125 mg; Mn 0.0956 g; Antioxidant 0.125 g; Fe 0.024 g; Cu 0.006 g; Se 0.24 g; Co 0.240 g,

$\mathrm{ME}=$ Metabolizable energy

\section{LABORATORY ANALYSIS}

The proximate composition of raw, fermented sorrel seed meal and experimental diets were determined according to methods described by AOAC (1990).

\section{STATISTICAL ANALYSIS}

Data generated were subjected to one-way analysis of variance (ANOVA) according to Steel and Torrie, (1980) and significant differences between treatment means were separated using Duncan's Multiple Range Test (Duncan, 1955).

\section{RESULTS AND DISCUSION \\ PROXIMATE COMPOSITION OF RAW AND FERMENTED SORREL SEED MEALS}

Table II showed the result of proximate composition of raw and fermented sorrel seed meal. Raw sorrel seed meals (RSSM) recorded $88.37 \%$ dry matter (DM) content and it increased to $91.32 \%$ after fermentation. FSSM recorded higher crude protein (CP) content of $36.95 \%$ compared to the raw seed (30.23\%). The ash content increased from $4.12 \%$ in the raw seed to $7.22 \%$ in the fermented seed. Higher ether extracts (EE) (5.25\%) was observed in the fermented sorrel seed meal as against $4.23 \%$ in the raw seed. Crude fibre (CF) content (14.32\%) was higher in the raw seed compared to $9.22 \%$ in the fermented seed. Nitrogen free extract was $41.39 \%$ in the fermented as against 47.10 in the raw. The values for alkaloid, phenol, glycosides, flavonoids, tannin and saponins were 2.16, 3.14, 2.84, 2.56, 2.13 and $1.72 \mathrm{mg} / 100 \mathrm{~g}$ in the raw seed respectively while fermented seed values were $1.00,1.32,0.99,1.03,0.93$ and $0.62 \mathrm{mg} / 100 \mathrm{~g}$ respectively.

The DM value observed were within the range of 87.90 - $94.30 \%$ for raw seeds and differently processed sorrel seed by Duwa et al. (2012). The increase in DM content of sorrel seed meal after processing has been reported by Ari et al. (2015). Higher CP content observed in fermented seed could possibly be due to the modification effect of the fermentation process that leads to crude protein improvement. The CF content of the raw and fermented sorrel seed is within the value of $13.01-15.50 \%$ CF reported by Duwa et al. (2012) for raw and differently processed sorrel seed meal, but higher than the range of $5.55-6.16 \%$ reported by Ari et al. (2015).The variations in the nutrient composition when compared to other studies could be attributed to the differences in agronomic practices, laboratory analysis and edaphic factors (Taiwo et al., 2005).

The result of the anti-nutritional factors (ANFs) in the seed showed that the raw seed has the highest concentration of all the ANFs. It is an indication that fermentation influenced the concentration of ANFs and increased the nutrient composition of sorrel seed, but did not influence the complete removal of the ANFs. The finding is in line with the report of Makkar et al. (1998), Wafar (2013) and Yakubu et al. (2017) when they subjected tropical legume seeds to different processing methods and recorded partial reduction of ANFs in the seeds 
Table 2: Proximate composition of raw and fermented sorrel seed meal (FSSM) (8 weeks)

\begin{tabular}{lll}
\hline Parameters $(\%)$ & Raw & Fermented \\
\hline Dry matter & 88.37 & 91.32 \\
Crude protein & 30.23 & 36.95 \\
Crude fibre & 14.32 & 9.22 \\
Ether extracts & 4.23 & 5.25 \\
Ash & 4.12 & 7.22 \\
Nitrogen free extracts & 47.10 & 41.36 \\
*ME Kcal/Kg & 3133.19 & 3260.68 \\
Anti- nutritional factors (mg/100g) & & \\
Tannin & 2.13 & 0.93 \\
Saponin & 1.72 & 0.62 \\
Phenol & 3.14 & 1.32 \\
Alkaloid & 2.16 & 1.00 \\
Glycosides & 2.84 & 0.99 \\
Flavonoids & 2.56 & 1.03 \\
\hline
\end{tabular}

${ }^{*} \mathrm{ME}(\mathrm{Kcal} / \mathrm{kg})$ was calculated using the formula of Pauzenga (1985). $\mathrm{ME}=37 \times \mathrm{CP}+81 \times \mathrm{EE}+35.5 \times \mathrm{NFE}$

\section{GROWTH PERFORMANCE OF WEANER RABBITS FED FERMENTED SORREL SEED MEAL}

The result of the growth performance of rabbits fed processed fed fermented sorrel seed meal is presented in Table III. The result showed no significant differences $(\mathrm{P}>0.05)$ between the dietary treatments for the parameters measured. Final body weight varied from $1770.12-1784.91 \mathrm{~g} /$ rabbit. Average daily feed intake (ADFI) ranged from $100.56 \mathrm{~g}$ in $\mathrm{T} 2$ to $102.56 \mathrm{~g}$ in $\mathrm{T} 4$ while average daily weight gain (ADWG) and Feed conversion was between $21.65 \mathrm{~g}$ in $\mathrm{T} 3$ to 21.94g in T1 and 4.62 in $\mathrm{T} 1$ and $\mathrm{T} 2$ to 4.74 in $\mathrm{T} 4$. The daily feed intake of rabbits observed were higher than range of 23.78 to $24.04 \mathrm{~g} /$ day reported by Amaefule et al. (2004) and $64.72-76.07 \mathrm{~g} /$ day reported by Biobaku and Dosumu, (2003) for rabbit raised under tropical conditions. However, the values are within the range of 91.25 - 175.41 reported by Kpanja et al. (2016) for rabbits fed fermented castor seed meal. Also, the daily weight gain and final body weight were higher than the range of 16.19 to $20.11 \mathrm{~g} / \mathrm{day}$ and 1154.00 to $1185.63 \mathrm{~g}$ reported by Ani and Ugwuowo, (2011) and Yakubu and Wafar, (2014). The non- significant differences in growth parameter measured could be due to the fact that fermentation reduced the ANFs in the sorrel seeds to a level that could not cause deleterious effect on the rabbit.

Table 3: Growth performance of weaner rabbits fed fermented sorrel seed meal (8 weeks)

\begin{tabular}{llllllll}
\hline & \multicolumn{7}{c}{ Dietary treatments } \\
\cline { 2 - 7 } Parameter & T1 $(0 \%)$ & T2 $(10 \%)$ & T3 $(20 \%)$ & T4 $(30 \%)$ & T5 $(40 \%)$ & SEM & p-value \\
\hline Initial body weight $(\mathrm{g})$ & 556.30 & 556.50 & 555.60 & 557.37 & 556.85 & 0.55 & $0.12^{\text {ns }}$ \\
Final body weight $(\mathrm{g})$ & 1784.91 & 1775.18 & 1767.78 & 1770.12 & 1783.17 & 1.77 & $1.45^{\text {ns }}$ \\
Total body weight $(\mathrm{g})$ & 1228.61 & 1218.68 & 1212.18 & 1212.75 & 1226.32 & 1.21 & $1.82^{\text {ns }}$ \\
Average daily weight $(\mathrm{g})$ & 21.94 & 21.76 & 21.65 & 21.66 & 21.90 & 0.02 & $0.34^{\text {ns }}$ \\
Average daily feed intake (g) & 101.43 & 100.56 & 101.67 & 102.56 & 101.45 & 0.10 & $0.67^{\text {ns }}$ \\
Feed conversion ratio & 4.62 & 4.62 & 4.70 & 4.74 & 4.63 & 0.04 & $0.11^{\text {ns }}$ \\
\hline
\end{tabular}

$\mathrm{ns}=$ not significant $(\mathrm{P}<0.05), \mathrm{SEM}=$ Standard error mean 


\section{CARCASS CHARACTERISTICS AND INTERNAL ORGANS WEIGHTS OF WEANER RABBITS FED FSSM}

The results of carcass characteristics and internal organs weights are shown in Table IV. The result showed no significantly $(\mathrm{P}>0.05)$ different in all the parameters evaluated. This is similar to the finding of Tuleun et al. (2011) who reported no significant effect in carcass characteristics of broiler chicken fed naturally fermented mucuna seed meal. The live body weight values obtained in this study are higher than the range $1603.00-1621.00 \mathrm{~g}$ reported by Tarimbuka et al. (2017) but within the range 985.08-1960.08 recorded by Omoikhoje et al. (2016). The dressed weight observed is higher than the range of 550 -820 g reported Tarimbuka et al. (2017) and 499.0- $592.00 \mathrm{~g}$ recorded by Wafar and Tarimbuka, (2016). The result of internal organs expressed as percentage of live weight were not significantly $(\mathrm{P}>0.05)$ affected by the level of FSSM in the diets. This suggests that cooking and fermentation process have rendered the level of anti- nutrients in raw sorrel seed inactive. Several studies have shown that the presence of anti-nutrients in high concentration causes growth depression and hypertrophy of organs such as liver and kidney. It is evident that feeding weaner rabbit with fermented sorrel seed meal did not affect these organs.

Table 4: Carcass characteristics and internal organs weight of weaner rabbits fed FSSM (8weeks)

\begin{tabular}{llllllll}
\hline Parameter & D1 (0\%) & D2 (10\%) & D3 (20\%) & D4 (30\%) & D5 (40) & SEM & p-value \\
\hline Live body weight (g) & 1782.11 & 1770.12 & 1742.9 & 1768.1 & 1781.67 & 1.76 & $0.24^{\mathrm{ns}}$ \\
Pelt weight (g) & 110.67 & 111.78 & 112.89 & 110.45 & 109.58 & 0.11 & $0.89^{\mathrm{ns}}$ \\
Dressing weight (g) & $980.9-$ & 981.78 & 979.90 & 980.56 & 981.6 & 0.98 & $0.23^{\mathrm{ns}}$ \\
Dressing \% & 55.04 & 55.46 & 56.22 & 55.46 & 55.09 & 0.56 & $0.13^{\mathrm{ns}}$ \\
Internal organ weights (\% live weight) & & & & & & \\
Lungs & 0.47 & 0.48 & 0.46 & 0.53 & 0.51 & 0.10 & $1.78^{\mathrm{ns}}$ \\
Heart & 0.21 & 0.18 & 0.18 & 0.20 & 0.20 & 0.10 & $0.45^{\mathrm{ns}}$ \\
Liver & 2.29 & 2.15 & 2.06 & 2.39 & 2.16 & 0.49 & $0.43^{\mathrm{ns}}$ \\
Kidney & 0.51 & 0.52 & 0.55 & 0.54 & 0.55 & 0.15 & $0.42^{\mathrm{ns}}$ \\
Stomach & 4.23 & 4.20 & 4.28 & 4.13 & 4.39 & 0.14 & $0.78^{\mathrm{ns}}$ \\
Small intestine & 6.13 & 6.08 & 6.36 & 6.21 & 5.82 & 0.06 & $1.69^{\mathrm{ns}}$ \\
Large intestine & 3.56 & 3.23 & 3.56 & 3.51 & 3.45 & 0.03 & $0.45^{\mathrm{ns}}$ \\
Ceaca & 0.38 & 0.37 & 0.35 & 0.37 & 0.38 & 0.07 & $0.24^{\mathrm{ns}}$ \\
Small intestine length (cm) & 65.89 & 65.23 & 64.34 & 67.34 & 64.89 & 0.65 & $0.34^{\mathrm{ns}}$ \\
Large intestine length (cm) & 18.78 & 18.67 & 17.99 & 18.03 & 18.67 & 0.18 & $2.45^{\mathrm{ns}}$ \\
\hline
\end{tabular}

$\mathrm{ns}=$ not significant $(\mathrm{P}<0.05), \mathrm{SEM}=$ Standard error mean

\section{CONCLUSION}

The result from this study showed that fermentation improves the crude protein content of sorrel seed meal as well and as well reduced the anti-nutritive factors. The growth performance parameters, carcass characteristics and internal organs were similar across the dietary treatments. In conclusion, fermented sorrel seed meal can be included in rabbits' diet up to $40 \%$ levels without adverse effect on performance, carcass characteristics and internal organs of rabbits. 


\section{REFERENCES}

Amaefule K.U, Nwaokoro C.C. and Iheukwumere F.C (2004). The effect of feeding graded levels of raw pigeon pea seed (Cajanus cajan) mealon the performance, nutrient retention and carcass characteristics of weaner rabbits. Nigerian Journal of Animal Production,31(2): 194-199.

Ani, A. O. and Ugwuowo, L. C. (2011). Response of weaner rabbits to diets containing graded levels of processed velvet beans (Mucuna pruriens). African Journal of Biotechnology, 10(66): 14984-14989

Alagbejo, M. D. (2000), "The potential of roselle as an industrial crop in Nigeria", NOMA, 14, 1 - 3. Allen, S. E., Grimshaw, H. E., Darkinson, J. A. and Quarmdy, C. (1974), "Chemical Analysis of Ecological Material. Blackwell Scientific Publication, London”, 67 - 89.

A.O.A.C, (1990) Official Methods of Analysis, 15th edition. Association of the official Analytical Chemists, Washington DC.

Aro, S.O., Aletor, V.O., Tewe, O.O., Fajemisin, A.N., Usifo, B. and Falowo, A.B. (2008). Preliminary investigation onthe nutrients, anti-nutrients and mineral composition of microbially fermented cassava starch residues.Proceedings of the $33^{\text {rd }}$ Annual . Conference. pp $248-251$.

Ari, M.M, Alu,S.E., Longtep, B.D., Alum,I., Usman,A.H and Kwassau, S.M (2015).Nutrient Composition and Phytochemical Screening of Crushed, Toasted and Fermented Roselle (Hibiscus sabdariffa L) Seeds. Annual Research \& Review in Biology 7(1): 39-44,

Ashom, S.A., Tuleun, C.DSylvanus and Carew, S.N (2014). Growth, Carcass and Internal Organ Characteristics of Finisher Broiler Chickens Fed Processed Roselle (Hibiscus sabdariffa L.) Seed Meal Diets. Journal of Biology, Agriculture and Healthcare, 4 (24) 141 -146

Badau, M.H., Nkama, A.I. and Jideani, A.I (2005). Phytic acid content and acid extractability of mineral in pearl millet as affected by germination time and cultivation. Journal of food chemistry, 2:425 - 435

Biobaku W.O. and Dosumu E.O. (2003). Growth response of rabbits fed graded levels of processed and un-dehulled sunflower seeds. Nigeria Journal of Animal Production, 30(2): 179-184.

Dashak, D. A. and Nwanegbo, V. (2002), "Chemical composition of the seeds and calyses of Hibiscus sabdariffa grown in Jos North Local Government Area of Plateau State", Journal of Natural Sciences, (5) 32 - 34.

Diarra, S. S., Kwari, I. D., Girgiri, Y. A., Saleh, B. and Igwebuike, J. U. (2011), "The use of sorrel (Hibiscussabdariffa) seed as a feed ingredient for poultry: A review", Research Opinions in Animal and Veterinary Sciences, 1(9), $573-577$

Duncan, D.B (1955). Multiple range and multiple F- test. Biometrics. 11:1-42

Duwa H., Oyawoye, E. O. and Njidda, A.A. (2012). Haematological responses and serum biochemical indices of broilers fed differently processed sorrel seed (Hibiscus sabdariffa) meal in semi-arid region of Nigeria", British Journal of Poultry Sciences, 1(1), 05-10.

Ismail, A. E., Ikram, H. K., and Nazri, H. S. M. (2008), "Roselle (Hibiscus sabdariffa L.) Seeds - Nutritional composition, protein quality and health benefits", Food, $1-16$.

Kpanja, E. J., Omage, J. J. and Makama, J. A. (2016). The Effect of Castor Seeds Processed by Soaking and Fermentation on the Performance, Biochemical Profile and Haematological Parameters of Rabbits. Journal of Animal Production Research, 28(2):239-244. 
Kwari, I. D., Igwebuike, J. U., Mohammed, I. D. and Diarra, S. S. (2011), "Growth, hematology and serum biochemistry of broiler chickens fed raw or differently processed sorrel (Hibiscus sabdariffa) seed meal in a semi-arid environment", International Journal of Science and Nature, 2(1), 22 - 27.

Mahadevan, N., Shivali and Kamboj, P. (2009), "Hibiscus sabdariffa Linn - An overview", Natural Product Radiance, 8(1), 77 - 83.

Makkar H. P. S, Aderibigbe, A. O. and Becker, K. (1998). Comparative evaluation of non-toxic and toxic varieties of Jatropha curcas for chemical composition, digestibility, protein degradability and toxic factors. Food Chemistry. 62:207-215.

Oboh, G. (2006). Nutrient enrichment of cassava peels using a mixed culture of Saccharomyces cerevisae andLactobacillus spp. solid media fermentation. Electronic Journal of Biotechnology, 9 (1): 46-49

Steel, R. C. D. and Torrie, J.D. (1980). Principles and Procedures of Statistics. McGraw Hills Books Co. New York

Taiwo, A. A., A. D. Adejuyigbe, J. A. adeowale, J. S. Osbotan, O. O. and David, O.O (2005) performance and nutrient digestibility of weaned rabbits fed forages supplemented with concentrates. Nigerian Journal of Animal Production, 32(1):74-78

Tang, J.W, Sun, H., Yao, X.H, Wu, Y.F., Wang, X. and Feng, J. (2012). Effects of Replacement of Soybean meal by Fermented Cotton seed meal on Growth Performance, Serum Biochemical parameters and immune function of yellow- feathered broilers. Asian- Aust. Journal of Animal Science, 25(3)393-400

Tarimbuka, L.I., Yusuf, H. B. and Wafar, R. J. (2017). Response of Weaner Rabbits Fed Toasted Sickle Pod (Senna occidentilis) Seed Meal. Asian Journal of Advances in Agricultural Research, 1(1): 1-7

Tuleun, C.D., Adenkola, A.Y., and Orayaga, K.T. (2011). Naturally fermented mucuna seed meal-based Diets: Effects on performance and Carcass characteristics of broiler chicken. Research Journal of Poultry Science. 4 (4) 50 $-55$

Yakubu, B and Wafar, R.J. (2014). Effects of Processing Methods of Leptadenia hastata on Growth Performance, Nutrient Digestibility and Carcass Characteristics of Weaner Rabbits. IOSR Journal of Agriculture and veterinary Science. 7 (1) 53-58

Yakubu, B, Y.H Aliyara, M Antyev and Mbahi, T.F. (2017). Effects of Fermented Jatropha (Jatrophacurcas) Seed Meal on Growth Performance, Carcass and Internal Organs Evaluation of Broiler Finisher Chickens. Greener Journal of Animal Breeding and Genetics, 3(1):001-008 doi.org/10.15580/GJABG.2017.1.041017049

Wafar, R.J and Tarimbuka L.I. (2016). Effects of substituting groundnut cake with supported by water spinach (Ipomoea aquatica) leaf meal on performance, carcass yield and blood profile of weaner rabbit. FUW Trends in Science \& Technology Journal, 1(1):238-242.

Wafar, R. J. (2013). Effects of Replacing Toasted Sorrel Seed (Hibiscus Sabdariffa) Meal for Soybean Meal in Broiler Finisher Diet. Journal of Animal Production Advances, 3(8): 247-253 